\title{
Passive smoking by self report and serum cotinine and the prevalence of respiratory and coronary heart disease in the Scottish heart health study
}

\author{
Hugh Tunstall-Pedoe, Colin A Brown, Mark Woodward, Roger Tavendale
}

\begin{abstract}
Study objective - To explore the relationship between self reported environmental tobacco smoke exposure (or passive smoking), the serum cotinine concentration, and evidence of respiratory or coronary disease in men and women who have never smoked.

Design - Cross sectional random population survey identifying disease markers and relating them to measures of passive smoking. Disease markers were previous medical diagnoses, response to standard symptom questionnaires, and electrocardiographic signs.
\end{abstract}

Setting - Samples of men and women aged 40-59 years drawn from general practitioner lists in 22 local government districts of Scotland, between 1984 and 1986. Participants - A total of 786 men and 1492 women who reported never having smoked tobacco, and who had serum cotinine concentrations below $17.5 \mathrm{ng} / \mathrm{ml}$, the cut off point for smoking "deceivers", took part. Results - Fewer than one third of never smokers reported no recent exposure to environmental tobacco smoke and the same proportion had no detectable cotinine. Women had lower cotinine values than men but reported more exposure to smoke. The correlation between the measures of exposure was poor. Self reported exposure showed strong, statistically significant, dose response relationships with respiratory symptoms and with the coronary disease markers. These relationships were weak or absent for serum cotinine, except for diagnosed coronary heart disease. Here the dose response gradient was as strong as that for self report, with an odds ratio of $2.7(95 \%$ CI $1.3,5 \cdot 6)$ for the highest $v$ the lowest exposure group, adjusted for age, housing tenure, total cholesterol, and blood pressure, and not explained by fibrinogen.

Conclusions - The validity of different measures of tobacco smoke exposure needs further investigation. The gradient of diagnosed coronary heart disease with both self reported exposure and serum cotinine was, however, surprisingly strong, statistically significant, and unexplained by other factors. These findings reinforce current policies to limit passive tobacco smoke exposure.

\section{(f Epidemiol Community Health 1995;49:139-143)}

Because of the low dose levels involved, investigation of the long term effects of passive exposure to tobacco smoke in non-smokers stretches epidemiological studies to their limits. If the excess risk over non-exposure is small, it may be explained by confounding factors, or the inclusion of furtive smokers, ${ }^{1}$ if it is large, it may lack a plausible biological mechanism. Opinion is divided on whether evidence on passive smoking in relation to coronary heart disease (CHD) is unconvincing, ${ }^{2}$ sufficiently suggestive that it cannot be ignored, ${ }^{3}$ or proving that thousands of deaths a year are caused by it. $^{4-6}$ The issue is of considerable importance to the public health.

Most studies of passive smoking have been done without biochemical validation to grade the exposure and exclude smoking deceivers. In a large cross sectional population survey, the Scottish heart health study (SHHS), we asked non-smokers about recent exposure to tobacco smoke and also measured their serum cotinine. ${ }^{7}$ We related these to questionnaire and electrocardiographic evidence of disease.

\section{Subjects and methods}

SURVEY METHOD

Men and women aged 40-59 years were recruited by random sampling from general practitioner lists between 1984 and $1986 .{ }^{8}$ Each was sent a "personal health record" to complete and a clinic appointment. The former included the standard Rose angina and possible infarction questionnaire; the Medical Research Council cough and phlegm questionnaire; questions on prior medical diagnoses, on current and former consumption of cigarette, pipe, or cigar tobacco; and the question, "Have you been exposed to tobacco smoke from someone else in the last three days?" with possible answers of: " 1 - yes, a lot; 2 -yes, some; 3 -yes, a little; 4 - none at all".

Relevant clinic procedures included checking the questionnaire, a 12 lead electrocardiogram, and venepuncture. Blood analyses included serum cholesterol, serum cotinine, assayed by 
Table 1 Distribution of men and women by $(A)$ self reported exposure to tobacco smoke over three days and by (B) serum cotinine group

\begin{tabular}{|c|c|c|c|c|c|c|c|c|c|}
\hline & \multicolumn{4}{|c|}{ (A) Self reported exposure group } & \multirow[t]{2}{*}{ All } & \multicolumn{4}{|c|}{ (B) Serum cotinine group } \\
\hline & None & Little & Some & A lot & & $I$ & $I I$ & III & IV \\
\hline \multicolumn{10}{|l|}{ Men } \\
\hline $\begin{array}{c}\text { No } \\
(\%) \\
\text { Women }\end{array}$ & $\begin{array}{l}190 \\
(24)\end{array}$ & $\begin{array}{l}347 \\
(44)\end{array}$ & $\begin{array}{l}176 \\
(22)\end{array}$ & $\begin{array}{c}73 \\
(9)\end{array}$ & $\begin{array}{c}786 \\
(100)\end{array}$ & $\begin{array}{l}208 \\
(27)\end{array}$ & $\begin{array}{l}241 \\
(31)\end{array}$ & $\begin{array}{l}204 \\
(26)\end{array}$ & $\begin{array}{l}133 \\
(17)\end{array}$ \\
\hline $\begin{array}{l}\text { No } \\
(\%) \\
\text { All }\end{array}$ & $\begin{array}{l}428 \\
(29)\end{array}$ & $\begin{array}{l}467 \\
(31)\end{array}$ & $\begin{array}{l}378 \\
(25)\end{array}$ & $\begin{array}{l}219 \\
(15)\end{array}$ & $\begin{array}{l}1492 \\
(100)\end{array}$ & $\begin{array}{l}548 \\
(37)\end{array}$ & $\begin{array}{l}433 \\
(29)\end{array}$ & $\begin{array}{l}349 \\
(24)\end{array}$ & $\begin{array}{l}162 \\
(11)\end{array}$ \\
\hline $\begin{array}{l}\text { No } \\
(\%)\end{array}$ & $\begin{array}{l}618 \\
(27)\end{array}$ & $\begin{array}{l}824 \\
(36)\end{array}$ & $\begin{array}{l}554 \\
(24)\end{array}$ & $\begin{array}{l}292 \\
(13)\end{array}$ & $\begin{array}{l}2278 \\
(100)\end{array}$ & $\begin{array}{l}756 \\
\text { (33) }\end{array}$ & $\begin{array}{l}674 \\
(30)\end{array}$ & $\begin{array}{l}553 \\
(24)\end{array}$ & $\begin{array}{l}295 \\
\text { (13) }\end{array}$ \\
\hline
\end{tabular}

Cotinine groups: I no detectable cotinine; II >0-1.05 ng/ml; III $1 \cdot 06-3.97 \mathrm{ng} / \mathrm{ml}$;V $3.98-17 \cdot 49 \mathrm{ng} / \mathrm{ml}$.

the method of Feyerabend, ${ }^{9}$ and plasma fibrinogen. ${ }^{10}$

DEFINITION OF PASSIVE SMOKING POPULATION AND GROUPINGS

Excluded from this analysis is anyone who admitted to active tobacco smoking currently or in the past, or who had no serum cotinine measurement, or who had a reading at or above $17.5 \mathrm{ng} / \mathrm{ml}$, our threshold for possible smoking deceivers. ${ }^{11}$ Replies to the question on passive smoking produced four unequal groups. Cut points were chosen in the serum cotinine results to give groups which corresponded in size to their questionnaire equivalents.

\section{DEFINITION OF DISEASE CATEGORIES}

Chronic cough was cough first thing in the morning or at any time during the day, for as much as three months each year.

Chronic phlegm was bringing up of phlegm first thing in the morning or at any time during the day, for as much as three months each year.

Questionnaire angina was chest discomfort on exertion relieved by rest, in those without diagnosed coronary heart disease.

Undiagnosed CHD (coronary heart disease) included questionnaire angina, or questionnaire "possible myocardial infarction"; or electrocardiographic findings of myocardial infarction or ischaemia (Minnesota codes for $\mathrm{Q}$ and $\mathrm{QS}$ waves $1 \cdot 1-1 \cdot 3$, ST depression $4 \cdot 1-4 \cdot 4$, $T$ inversion and flattening $5 \cdot 1-5 \cdot 3$ or left bundle branch block $7 \cdot 1)^{12}$ in those without diagnosed coronary heart disease.

Diagnosed $C H D$ was the reporting of a medical diagnosis of angina, myocardial infarction, coronary thrombosis, or a heart attack.

Table 2 Distribution across self reported exposure and serum cotinine groups (sexes combined)

\begin{tabular}{|c|c|c|c|c|c|c|}
\hline \multirow[t]{2}{*}{ Self report group } & & \multicolumn{4}{|c|}{ Serum cotinine group } & \multirow[b]{2}{*}{ All } \\
\hline & & $I$ & II & $I I I$ & IV & \\
\hline None & $\begin{array}{l}\text { No } \\
\text { O/E }\end{array}$ & $\begin{array}{l}285 \\
1.39\end{array}$ & $\begin{array}{l}194 \\
1.06\end{array}$ & $\begin{array}{l}103 \\
0.69\end{array}$ & $\begin{array}{l}36 \\
0.45\end{array}$ & 618 \\
\hline Little & $\begin{array}{l}\text { No } \\
\mathrm{O} / \mathrm{E}\end{array}$ & $\begin{array}{c}274 \\
1 \cdot 01\end{array}$ & 251.04 & $\begin{array}{c}199 \\
1.00\end{array}$ & $\begin{array}{l}90 \\
0.86\end{array}$ & 814 \\
\hline Some & $\begin{array}{l}\text { No } \\
\text { O/E }\end{array}$ & $\begin{array}{l}140 \\
0.76\end{array}$ & $\begin{array}{r}152 \\
0.93\end{array}$ & $\begin{array}{r}167 \\
1 \cdot 25\end{array}$ & $\begin{array}{l}95 \\
1 \cdot 32\end{array}$ & 554 \\
\hline A lot & $\begin{array}{l}\text { No } \\
\text { O/E }\end{array}$ & $\begin{array}{l}57 \\
0.59\end{array}$ & $\begin{array}{l}77 \\
0.89\end{array}$ & $\begin{array}{l}84 \\
1 \cdot 19\end{array}$ & $\begin{array}{l}74 \\
1.96\end{array}$ & 292 \\
\hline All & No & 756 & 674 & 553 & 295 & 2278 \\
\hline
\end{tabular}

No is the observed number in each subgroup, and $\mathrm{O} / \mathrm{E}$ the ratio between the observed number and that expected in the subgroup if there were no association between self report and serum cotinine.
All CHD was the preceding two categories combined.

\section{STATISTICAL METHODS}

The relationship of the self report and cotinine grouping to the different diseases was examined by logistic regression analysis using GLIM. ${ }^{13}$ Prevalence odds ratios were calculated relative to the least exposure group, with $95 \%$ confidence limits. Odds ratios for coronary heart disease were adjusted for age, housing tenure, serum cholesterol, and diastolic blood pressure, possible confounding factors identified in previous analyses, ${ }^{14}$ while those for respiratory disease were adjusted for age and housing tenure.

\section{Results}

\section{POPULATION FOR STUDY}

The SHHS response rate was $74 \%$, yielding 5123 men and 5236 women. Active cigarette smoking involved $38 \%$ in both sexes. More men were pipe, cigar, or ex-smokers. After excluding smokers, people with no cotinine result, ${ }^{7}$ and 21 men and 28 women with cotinine readings at or above $17.5 \mathrm{ng} / \mathrm{ml}^{11}$ (possible deceivers) 786 men and 1492 women allegedly, never smokers were left. These subjects figure in subsequent analyses, unless missing data or specific definitions exclude them.

PASSIVE SMOKING GROUPS BY THE TWO METHODS OF DEFINITION

The passive smoking groups, defined by self report are shown in table $1(\mathrm{~A})$, and by serum cotinine in $1(B)$. Only $27 \%$ reported no exposure to tobacco smoke, while $13 \%$ reported a lot. The distribution across the four groups was different in the two sexes $\left(\chi^{2}=47, \mathrm{p}<0 \cdot 0001\right)$, more women than men reported both no exposure and a lot of exposure. Cotinine readings of zero accounted for $33 \%$ of never smokers (group I). Subsequent cut off points were designed to match the self report groups. Group II had readings from $0.01 \mathrm{ng} / \mathrm{ml}$ to $1.05 \mathrm{ng} / \mathrm{ml}$, group III $1.06-3.97 \mathrm{ng} / \mathrm{ml}$, and group IV 3.98 to $17.49 \mathrm{ng} / \mathrm{ml}$. The sexes differed in serum cotinine groups $\left(\chi^{2}=34, p<0.0001\right)$ in that women scored lower than men. Nonetheless there were no important differences or interactions in relation to sex in subsequent analyses and the results are combined.

The joint distribution by passive smoking classes is shown in table 2 . Agreement means 
Table 3 Disease prevalence and odds ratio trends across categories of passive smoking defined by self reported exposure and by serum cotinine

\begin{tabular}{|c|c|c|c|c|c|c|c|c|c|}
\hline & \multirow[b]{2}{*}{ All } & \multicolumn{4}{|c|}{ Reported exposure group } & \multicolumn{4}{|c|}{ Serum cotinine group } \\
\hline & & None & Little & Some & A lot & $I$ & $I I$ & $I I I$ & $I V$ \\
\hline $\begin{array}{l}\text { Chronic cough } \\
\text { No positive } \\
\text { Prevalence (\%) } \\
\text { Odds ratio* } \\
(95 \% \mathrm{CI})\end{array}$ & $\begin{array}{r}121 \\
(5 \cdot 5)\end{array}$ & $\begin{array}{c}27 \\
(4 \cdot 5) \\
1 \cdot 0\end{array}$ & $\begin{array}{l}36 \\
(4 \cdot 6) \\
1 \cdot 0 \\
(0 \cdot 6,1 \cdot 7)\end{array}$ & $\begin{array}{l}30 \\
(5 \cdot 5) \\
1 \cdot 2 \\
(0 \cdot 7,2 \cdot 1)\end{array}$ & $\begin{array}{l}28 \\
(9 \cdot 9) \\
2 \cdot 3 \\
(1 \cdot 3,3 \cdot 9)\end{array}$ & $\begin{array}{c}39 \\
(5 \cdot 3) \\
1 \cdot 0\end{array}$ & $\begin{array}{l}40 \\
(6 \cdot 1) \\
1 \cdot 2 \\
(0 \cdot 7,1 \cdot 8)\end{array}$ & $\begin{array}{l}25 \\
(4 \cdot 7) \\
0 \cdot 8 \\
(0 \cdot 5,1 \cdot 4)\end{array}$ & $\begin{array}{l}17 \\
(5 \cdot 9) \\
1 \cdot 1 \\
(0 \cdot 6,1 \cdot 9)\end{array}$ \\
\hline $\begin{array}{l}\text { Chronic phlegm } \\
\text { No positive } \\
\text { Prevalence (\%) } \\
\text { Odds ratio* } \\
(95 \% \mathrm{CI})\end{array}$ & $\begin{array}{r}142 \\
(6 \cdot 4)\end{array}$ & $\begin{array}{c}32 \\
(5 \cdot 3) \\
1 \cdot 0\end{array}$ & $\begin{array}{l}38 \\
(4 \cdot 8) \\
0 \cdot 9 \\
(0 \cdot 6,1 \cdot 5)\end{array}$ & $\begin{array}{l}40 \\
(7 \cdot 4) \\
1 \cdot 4 \\
(0 \cdot 9,2 \cdot 3)\end{array}$ & $\begin{array}{l}32 \\
(11 \cdot 3) \\
2 \cdot 3 \\
(1 \cdot 4,3 \cdot 9)\end{array}$ & $\begin{array}{c}42 \\
(5 \cdot 7) \\
1 \cdot 0\end{array}$ & $\begin{array}{l}48 \\
(7 \cdot 3) \\
1 \cdot 3 \\
(0 \cdot 9,2 \cdot 0)\end{array}$ & $\begin{array}{l}33 \\
(6 \cdot 1) \\
1 \cdot 1 \\
(0 \cdot 7,1 \cdot 7)\end{array}$ & $\begin{array}{l}19 \\
(6 \cdot 6) \\
1 \cdot 2 \\
(0 \cdot 7,2 \cdot 0)\end{array}$ \\
\hline $\begin{array}{l}\text { Questionnaire angina } \\
\text { No positive } \\
\text { Prevalence }(\%) \\
\text { Odds ratiof } \\
(95 \% \mathrm{CI})\end{array}$ & $\begin{array}{r}104 \\
(5 \cdot 6)\end{array}$ & $\begin{array}{c}20 \\
(3 \cdot 9) \\
1 \cdot 0\end{array}$ & $\begin{array}{l}33 \\
(4 \cdot 9) \\
1 \cdot 3 \\
(0 \cdot 7,2 \cdot 3)\end{array}$ & $\begin{array}{l}30 \\
(6 \cdot 8) \\
1 \cdot 6 \\
(0 \cdot 9,2 \cdot 8)\end{array}$ & $\begin{array}{l}21 \\
(8 \cdot 9) \\
2 \cdot 1 \\
(1 \cdot 1,3 \cdot 9)\end{array}$ & $\begin{array}{c}35 \\
(5 \cdot 6) \\
1 \cdot 0\end{array}$ & $\begin{array}{l}29 \\
(5 \cdot 1) \\
0 \cdot 9 \\
(0 \cdot 5,1 \cdot 4)\end{array}$ & $\begin{array}{l}28 \\
(6 \cdot 4) \\
1 \cdot 0 \\
(0 \cdot 6,1 \cdot 7)\end{array}$ & $\begin{array}{l}12 \\
(5 \cdot 0) \\
0 \cdot 8 \\
(0 \cdot 4,1 \cdot 5)\end{array}$ \\
\hline $\begin{array}{l}\text { Undiagnosed } C H D \\
\text { No positive } \\
\text { Prevalence }(\%) \\
\text { Odds ratiof } \\
(95 \% \mathrm{CI})\end{array}$ & $\begin{array}{c}358 \\
(16 \cdot 8)\end{array}$ & $\begin{array}{l}83 \\
(14 \cdot 3) \\
1 \cdot 0\end{array}$ & $\begin{array}{l}125 \\
(16 \cdot 3) \\
1 \cdot 2 \\
(0 \cdot 9,1 \cdot 6)\end{array}$ & $\begin{array}{l}98 \\
(19 \cdot 1) \\
1 \cdot 4 \\
(1 \cdot 0,1 \cdot 9)\end{array}$ & $\begin{array}{l}52 \\
(19 \cdot 5) \\
1 \cdot 4 \\
(0 \cdot 9,2 \cdot 0)\end{array}$ & $\begin{array}{l}114 \\
(16 \cdot 1) \\
1 \cdot 0\end{array}$ & $\begin{array}{l}96 \\
(15 \cdot 2) \\
0 \cdot 9 \\
(0 \cdot 7,1 \cdot 2)\end{array}$ & $\begin{array}{l}101 \\
(19 \cdot 7) \\
1 \cdot 2 \\
(0 \cdot 9,1 \cdot 6)\end{array}$ & $\begin{array}{l}47 \\
(17 \cdot 0) \\
1 \cdot 0 \\
(0 \cdot 7,1 \cdot 4)\end{array}$ \\
\hline $\begin{array}{l}\text { Diagnosed CHD } \\
\text { No positive } \\
\text { Prevalence (\%) } \\
\text { Odds ratioł } \\
(95 \% \mathrm{CI})\end{array}$ & $\begin{array}{r}70 \\
(3 \cdot 3)\end{array}$ & $\begin{array}{c}16 \\
(2 \cdot 8) \\
1 \cdot 0\end{array}$ & $\begin{array}{l}16 \\
(2 \cdot 1) \\
0 \cdot 8 \\
(0 \cdot 4,1 \cdot 7)\end{array}$ & $\begin{array}{l}21 \\
(4 \cdot 1) \\
1 \cdot 6 \\
(0 \cdot 8,3 \cdot 1)\end{array}$ & $\begin{array}{l}17 \\
(6 \cdot 4) \\
2 \cdot 4 \\
(1 \cdot 1,4 \cdot 8)\end{array}$ & $\begin{array}{c}15 \\
(2 \cdot 1) \\
1 \cdot 0\end{array}$ & $\begin{array}{l}20 \\
(3 \cdot 2) \\
1 \cdot 5 \\
(0 \cdot 8,3 \cdot 0)\end{array}$ & $\begin{array}{l}19 \\
(3 \cdot 7) \\
1 \cdot 7 \\
(0 \cdot 8,3 \cdot 3)\end{array}$ & $\begin{array}{l}16 \\
(5 \cdot 8) \\
2 \cdot 7 \\
(1 \cdot 3,5 \cdot 6)\end{array}$ \\
\hline $\begin{array}{l}\text { All } C H D \\
\text { No positive } \\
\text { Prevalence (\%) } \\
\text { Odds ratiot } \\
(95 \% \mathrm{CI})\end{array}$ & $\begin{array}{c}428 \\
(20 \cdot 1)\end{array}$ & $\begin{array}{l}99 \\
(17 \cdot 0) \\
1 \cdot 0\end{array}$ & $\begin{array}{l}141 \\
(18 \cdot 4) \\
1 \cdot 2 \\
(0 \cdot 9,1 \cdot 5)\end{array}$ & $\begin{array}{l}119 \\
(23 \cdot 2) \\
1 \cdot 5 \\
(1 \cdot 1,2 \cdot 0)\end{array}$ & $\begin{array}{l}69 \\
(25 \cdot 9) \\
1 \cdot 6 \\
(1 \cdot 1,2 \cdot 4)\end{array}$ & $\begin{array}{l}129 \\
(18 \cdot 2) \\
1 \cdot 0\end{array}$ & $\begin{array}{l}116 \\
(18 \cdot 4) \\
1 \cdot 0 \\
(0 \cdot 8,1 \cdot 3)\end{array}$ & $\begin{array}{l}120 \\
(23 \cdot 4) \\
1 \cdot 3 \\
(1 \cdot 0,1 \cdot 7)\end{array}$ & $\begin{array}{l}63 \\
(22 \cdot 8) \\
1 \cdot 2 \\
(0 \cdot 9,1 \cdot 7)\end{array}$ \\
\hline $\begin{array}{l}\text { Overall no } \\
\text { Plasma fibrinogen }(\mathrm{g} / \mathrm{l}) \dagger \\
\text { Standard error }\end{array}$ & $\begin{array}{r}2278 \\
2 \cdot 21 \\
0.02\end{array}$ & $\begin{array}{l}618 \\
2 \cdot 23 \\
0 \cdot 03\end{array}$ & $\begin{array}{l}824 \\
2 \cdot 21 \\
0 \cdot 03\end{array}$ & $\begin{array}{c}554 \\
2 \cdot 20 \\
0 \cdot 03\end{array}$ & $\begin{array}{l}292 \\
2 \cdot 26 \\
0 \cdot 04\end{array}$ & $\begin{array}{l}756 \\
2 \cdot 19 \\
0 \cdot 03\end{array}$ & $\begin{array}{c}674 \\
2 \cdot 21 \\
0.03\end{array}$ & $\begin{array}{l}553 \\
2 \cdot 26 \\
0 \cdot 03\end{array}$ & $\begin{array}{l}295 \\
2 \cdot 23 \\
0 \cdot 04\end{array}$ \\
\hline
\end{tabular}

* Adjusted for age and housing tenure;

† Adjusted for age, housing tenure, and also for cholesterol and diastolic blood pressure.

greater numbers in cells where criteria are congruent. This happens, but not enough to make one measure a reliable predictor of the other. Cells with congruent categories contain about twice the number expected, while incongruent cells contain half the number expected if there were no association.

PREVALENCE OF DISEASE AND ODDS RATIO BY DEGREE OF PASSIVE SMOKING

Table 3 shows the prevalence and odds ratios for respiratory and coronary heart disease first for self reported passive smoking, and then for serum cotinine groups. Chronic cough and chronic phlegm each occur in about $6 \%$ of the population. The prevalence is twice as high in those reporting exposure to "a lot" of tobacco smoke as "none". The odds ratios are significantly raised, with $95 \%$ confidence limits above $1 \cdot 00$. Adjustment for age and housing tenure had little effect. Questionnaire angina shows a clear gradient of prevalence with increasing self reported exposure, with the odds ratio in the highest exposure group of $2 \cdot 1$, after added adjustment for cholesterol and diastolic blood pressure. The 358 cases of undiagnosed $C H D$ also show a gradient in odds ratios but this does not reach statistical significance. With smaller numbers, diagnosed $C H D$ shows a significantly raised odds ratio in the high exposure group. When all $C H D$ categories are combined there is a steady, significant gradient.

Results for serum cotinine do not corroborate self report. The raised odds ratios and statistical significance disappear with respiratory symptoms, and questionnaire angina. When all $C H D$ categories are combined, the odds ratio in group IV is lower than that in the comparable "a lot" group and it does not reach statistical significance after adjustment, although this is reached if groups III and IV are combined. In diagnosed CHD the gradient is stronger than for self report. The odds ratio for group IV is significantly high, and this is also true for groups III and IV combined.

Plasma fibrinogen findings do not explain the raised odds ratios for coronary heart disease. Any possible gradient by passive smoking group is tiny (table 3 ). The correlation coefficient between plasma fibrinogen and serum cotinine in never smokers before adjustment was $0 \cdot 038$. After adjustment for the factors listed it was 0.033 , and insignificant. By contrast with the gradient shown, the mean fibrinogen in active tobacco smokers in the SHHS was $2.46 \mathrm{~g} / 1$, and in ex-smokers $2 \cdot 25 \mathrm{~g} / 1$, after adjustment for the same factors.

\section{Discussion}

TOBACCO SMOKE EXPOSURE IN THE GENERAL POPULATION

Only one third of never smokers had no recent exposure to tobacco smoke by either method of assessment, or one sixth if they are combined (table 2). This implies that only $5-10 \%$ of the whole SHHS population, typical of Scotland in 1984-6, had neither smoked in the past or been passively exposed in the last few days. This estimate may be too low if nicotine in food affects the serum cotinine, ${ }^{1516}$ or too high, as assay methods are not improved and more sensitive $^{1617}$ than the one used for the SHHS.9 
DISAGREEMENT BETWEEN SELF REPORTED DEGREE OF EXPOSURE AND SERUM COTININE MEASUREMENTS

Their poor correlation with each other and disparate association with disease undermine the validity of the two measures of passive smoking. We doubt that either measure is more ephemeral as exposure is usually chronic, and responses and serum cotinine concentrations did not fluctuate much by day of the week. Self report concerned exposure during three days, and the half life of serum cotinine in nonsmokers can be as much as 40 hours. $^{18}$

It is claimed that cotinine is a poor measure of passive smoking ${ }^{15}$ because of individual variation in nicotine metabolism ${ }^{19}$ and traces of nicotine in foodstuffs. ${ }^{16}$ The latter claims do not seem to have been substantiated in human data; our analyses from the SHHS refute the claim that heavy tea consumption would interfere with the relationship between passive smoking and serum cotinine. ${ }^{20}$ The four cotinine groups cover a huge range of readings so a degree of variation in metabolism and imprecision in the cotinine assay ${ }^{9}$ should not invalidate the broad ranking. Amalgamation into two rather than four groups does not change the study findings.

Self report could be biased. Our cigarette smoking men and women ran similar serum cotinine concentrations for the same cigarette consumption, ${ }^{7}$ so the lower cotinine in women shown here for higher self reported exposure suggests a possible bias in reporting of the latter. Those study participants with hyperreactive bronchial mucosa might react to tobacco smoke by exaggerating exposure (questionnaire positive) and avoiding it (cotinine negative). Twenty four of 188 of those complaining of cough or phlegm were on treatment for asthma with bronchodilators or corticosteroids or both. Participants with symptoms of disease might exaggerate exposure because they had heard of an association. This is plausible in the middle 1980 s for respiratory disease, but less so for diagnosed coronary heart disease and implausible for its undiagnosed manifestations. Table 3 shows paradoxically that it is the undiagnosed group which show a greater odds ratio for self report than for cotinine, whereas the diagnosed group shows the opposite. We cannot therefore explain the discrepancies between self report and serum cotinine, and consider that more needs to be done on the validation of these measures as passive smoking becomes of increasing public health and medico-legal interest. If self reported exposure is unreliable it still suggests that those with early markers of disease tolerate smoke exposure badly.

\section{PASSIVE SMOKING AND CORONARY HEART} DISEASE

Self reported exposure shows a significant gradient for all categories of coronary heart disease, considered separately or together (table 3 ). If exposure is assessed using cotinine only diagnosed $C H D$ shows a significantly high odds ratio in the highest exposure group after ad- justment whereas all $C H D$ (to which it contributes) shows a significant excess only if groups III and IV are combined. Undiagnosed $C H D$ shows slight evidence of a gradient but questionnaire angina shows none at all. A possible explanation for the greater gradient with diagnosed $C H D$ is its greater specificity. The undiagnosed category includes more mild and asymptomatic cases, but it is diluted with false positives.

The odds ratios of interest are those for diagnosed $C H D$ and all $C H D$. After adjustment, the odds ratios for the top group are 2.4 and 1.6 (see table 3 ) for self report, and 2.7 and 1.2 for cotinine. Odds ratios in published studies of heart disease and passive smoking show considerable variation, ranging from 0.97 to $3 \cdot 0$, but some of these lack precision because of small numbers. ${ }^{6}$ The Midspan study, also from Scotland, reported a rate ratio of $2 \cdot 01$, with $95 \%$ confidence limits of $1 \cdot 21,3 \cdot 35$, based on a 12 year follow up. ${ }^{21}$ Our prevalence results are consistent. If the odds ratio is high in this region, the question arises as to whether the increase is consequent on misclassification, related directly and causally to passive smoking itself, or to lifestyle and other factors associated with it, or to both.

The mechanism by which active smoking causes heart disease is not known, although some authors, and our own analyses, suggest a strong relationship with fibrinogen. ${ }^{1022}$ Fibrinogen values show a tiny gradient (table 3 ), inadequate to explain the odds ratios we found. We have excluded current smoking deceivers by our cotinine barrier, but cannot exclude inaccurate questionnaire responses on past smoking history or occasional smoking. However, the numbers of deceivers involved, and their excess risk, would need to be very considerable to produce the odds ratios we have found, nor would we expect concealed exsmokers to necessarily expose themselves currently to high levels of passive smoking.

We have adjusted for other confounding factors for coronary heart disease such as coronary risk factors and social status ${ }^{14}$ before presenting these odds ratios. It is unlikely that we have corrected for everything, but we would not expect confounding factors to account for such a large residual effect.

We have therefore found a significantly increased prevalence of diagnosed coronary heart disease, associated with environmental tobacco smoke, otherwise known as passive smoking, which we cannot explain. Although unexplained, these findings tend to support current attempts to minimise passive exposure to tobacco smoke.

The Scottish heart health study was funded predominantly by the Scottish Office Home and Health Department, with the smoking related component funded by the Tobacco Products Research Trust. The opinions expressed in this paper are those of the authors.

1 Lee PN. Misclassification of smoking habits and passive smok ing: a review of the evidence. Springer-Verlag, Berlin, 1988. 2 Mantel N. Dubious evidence of heart and cancer death due to passive smoking. F Clin Epidemiol 1992;45:809-813.

Beaglehole R. Does passive smoking cause heart disease? The evidence is strong enough to warrant measures to reduce exposure. $B M \mathcal{F}^{\prime} 1990 ; 310: 1343-44$.

4 Taylor AE, Johnson DC, Kazemi H. Environmental tobacco 
smoke for cardiovascular disease: a position paper from the Council of Cardiopulmonary and Critical Care, American Heart Association. Circulation 1992;86:699-702.

5 Glantz SA, Parmley WW. Passive smoking causes heart Glantz SA, Parmley WW. Passive smoking causes heart disease and lung cancer. F Clin Epidemiol 1992;45:815-19.
Steenland K. Passive smoking and the risk of heart disease. Steenland K. Passive smo

7 Woodward M, Tunstall-Pedoe H, Smith WCS, Tavendale R. Smoking characteristics and inhalation biochemistry in the Scottish population. F Clin Epidemiol 1991;44:140510.

8 Smith WCS, Crombie IK, Tavendale R, Irving JM, Kenicer MB, Tunstall-Pedoe H. The Scottish heart health study: objectives and development of methods. Health Bull (Edinb) 1987;45:211-17.

9 Feyerabend C, Russell MAH. Rapid gas-liquid chromatographic determination of cotinine in biological fluids. Analyst 1980;105:998-1001.

10 Lee AJ, Smith WCS, Lowe GDO, Tunstall-Pedoe H. Plasma fibrinogen and coronary risk factors: the Scottish heart fibrinogen and coronary risk factors: the Scot

11 Woodward M. Tunstall-Pedoe H. An iterative technique for identifying smoking deceivers with application to the Scottish heart health study. Prev Med 1992;21:88-97.

12 Prineas RJ, Crow RS, Blackburn H. The Minnesota code manual of electrocardiographic findings. Bristol: John Wright, 1982.

13 Payne CD (ed). Generalized linear interactive modelling manual. London 1987: Royal Statistical Society.

14 Woodward M, Shewry MC, Smith WCS, Tunstall-Pedoe
H. Social status and coronary heart disease: results from the Scottish heart health study. Prev Med 1992;21:136148.

15 Idle JR. Titrating exposure to tobacco smoke using cotinine - a minefield of misunderstandings. F Clin Epidemiol 1990; 43:313-17.

16 Domino ED, Hornbach E, Demana T. The nicotine content of common vegetables. $N$ Engl f Med 1993;329:437.

17 Feyerabend C, Russell MAH. A rapid gas-liquid chromatographic method for the determination of cotinine and nicotine in biological fluids. F Pharm Pharmacol 1990;42: 450-52.

18 Sepkovic DW, Haley HJ, Hoffman D. Elimination from the body of tobacco products by smokers and passive smokers. FAMA 1986;256:863.

19 Cholerton S, Arpahahi A, McCracken N, et al. Poor metabolisers of nicotine and CYP2D6 polymorphism. Lancet 1994:343:62-3.

20 Tunstall-Pedoe $\mathrm{H}$, Woodward $\mathrm{M}$, Brown CA. Tea drinking, passive smoking, smoking deception and serum cotinine in the Scottish heart health study. F Clin Epidemiol 1991; 44:1411-14.

21 Hole D, Gillis C, Chopra C. Passive smoking and cardiorespiratory health in a general population in the west of Scotland. BMf 1990;299:423-27.

22 Lee AJ, Lowe GDO, Woodward $M$, Tunstall-Pedoe $H$. Fibrinogen in relation to personal history of prevalent hypertension, diabetes, stroke, intermittent claudication, coronary heart disease and family history: the Scottish heart health study. Br Heart f 1993;69:338-42. 